\title{
Late Paleocene to early Oligocene dinoflagellate cysts of the Zagros basin, west Iran (palaeopalynology and palynostratography)
}

\author{
*11ALI AKBAR, JN; EBRAHIM,GN \\ ${ }^{I}$ Department of Geology, Tehran Shomal Branch, Islamic Azad University, Tehran, Iran \\ (*Corresponding Author E- mail: ajanaky_15@yahoo.com) \\ ${ }^{2}$ Department of Geology, University College of Science, \\ University of Tehran, Tehran, Iran (eghasemi@khayam.ut.ac.ir)
}

KEYWORDS: Pabdeh Formation; Dinoflagellatecyst; Paleogene; Palynostratigraphy; Thermalmaturity.

\begin{abstract}
Palynological investigation about 120 samples from 460m thick outcrop section of late Paleocene to early Oligocene of the Pabdeh Formation, southwestern in Iran yield 55 species of dinoflagellate results to defined 7 biozone. The quantities of marine palynomorph elements are indicated of open marine at this time, but a low increase number of spore and pollen in some of the sample indicated the condition for growth forest are suitable that consequent increase the harm climate and humidity. The species are common with different latitude and most of them cosmopolitan. Thermal maturity index measurement indicates oil prone in most of the samples.
\end{abstract}

(C) JASEM

http://dx.doi.org/10.4314/jasem/v19i3.18

\section{Introduction}

The first studies on fossil dinoflagellates from Western Iran were made by Zahiryin 1982 (Zahiri, 1982). The principal intent of these investigations was identification of dinoflagellate cysts. The stratigraphic application of dinoflagellate cysts in this area started only at the end of 1982 when a few boreholes were investigated and the first dinoflagellate cyst zones were erected (Zahiri, 1982). Later on more studies conducted on palynostratigraphy of some parts of the Zagros basin (e.g. Ghasemi-Nejad et al.,2006, Rabbani et al., 2013). As the Pabdeh Formation which is lithologically made up of shale, calcareous shale and limestone, is a relatively known source rock in the Zagros basin, palynological studies on these strata could help to establish a stratigraphic framework for the formation to be further investigated in terms of potential for petroleum generation.

\section{MATERIALS ANDMETHODS}

A total of 125 rock samples from the Siah anticline section were collected. The samples were processed using palynological techniques in several steps according to palynological standard methods (Traverse,1988,pp.456-479). About 30 grams of rock samples was used for processing. The samples were first crushed and washed, then treated with $33 \% \mathrm{HCl}$ and later with $40 \%$ HF. After these chemical preparation steps, the material was sieved through a 20 micron nylon mesh. The materials residue coarser than 20 micron were used for palynological study.

Previous Studies: There is afew record of dinoflagellate cysts from the Pabdeh Formation of the Zagros basin in the published literature (e.g. Rabbani et al., 2013). However, several good works have been published on foraminiferal biostratigraphy of the formation (e. g. Biranvand et al. ) presenting precise biostratigraphy and giving in general an age of Paleocene to Miocene to the formation.

The Pabdeh Formationisa known surcerock for the Asmarire servoir, one of the largest source rocks in the Middle East (Motiei, 2003). For this reason,it is important to study palynology and palynostratigraphy of the formation and to establish a precise stratigraphic framework for this formation.

Geological Setting: The Pabdeh Formation crops out extensively in KohgiluyehvaBoyerahmad in Zagros basin, southwest Iran (Fig. 1). The lower contact with shalesand Limestones of the Gurpi Formation and the upper contact with limestone and marls of the Asmari Formation are both comformable.

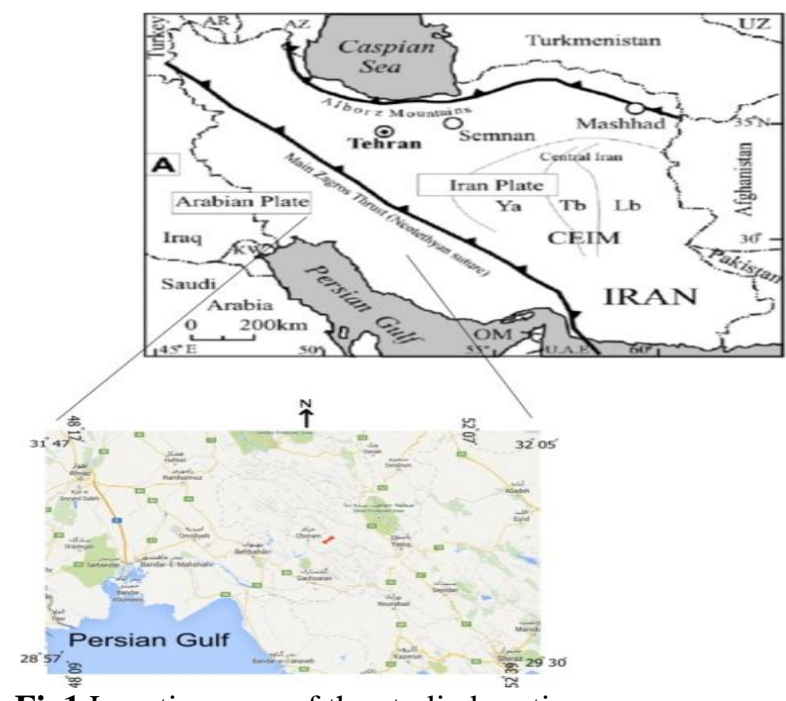

Fig1.Location map of the studied section. 
Biostratigraphy: Stratigraphic distribution of dinoflagellate cysts recorded in this study are displayed in Figures 2. Based on the composition of the assemblages recorded seven dinoflagellate cyst zones are differentiated ranging in age from late Paleocene to early Oligocene. The most productive and rich associations have been revealed from the Maastrichtian, Danian and Ypresian intervals. The zones erected here can be compared with those of different parts in Europe and Urals (Table1) generally but a complete correlation and zonation has yet to be erected for the Tertiary basins around the world. The zonation established here is discussed below:

Biozone1: Apectodinium parvum interval zone Age: late Paleocene (thanetian),Occurrence:from 45.55 to $50.91 \mathrm{~m}$

Definition: this zone has been defined as the interval from the LAD of Apectodinium parvum to the LAD of Areoligera gippingensis. Acompanying taxa include: Apectodinium, homomorphus,

Melitasphaeridium, pseudorecurvatum,

Areosphaeridium capricornum.

The index species, Areoligera gippingensis has been recorded from:

Paleocene, Germany (Gocht, 1969); MaastrictianUpper Paleocene, offshore South East Canada (Williams and Bujak,1977a); Lower Eocene of England (Williams and Downie,1966c); Upper Paleocene- basal Upper Eocene of North West Germany (Köthe, 1990)

Biozone 2: Phelodinium kozlowskii Interval zone

Age:Early Eocene (Eypresian), Occurrence: from $50.91 \mathrm{~m}$ to $138.24 \mathrm{~m}$

Definition:this zone has been defined as the interval from the LAD of Enneadocysta arcuatum to the LAD of Phelodinium kozlowskii. Acompanying taxa include Chiropteridium galea ,Cleistosphaeridium diversispinosum, Distatodiniumtenerum, Impagidiniumsp.

Biozone 3: Deflandrea phosphoritica Interval zone This has been introduced as a local biozone by Morgans et al. (2004) but it can be compared with Deflandrea oebisfeldensis interval zone introduced by Nøhr-Hansen (2002).

Age:Early Eocene (Eypresian), Occurrence: from $138.24 \mathrm{~m}$ to $158.9 \mathrm{~m}$

Definition:this zone has been defined as the interval from the LAD of Deflandrea phosphoritica to the LAD of Lejeunecysta fallax. Acompanying taxa include Chiropteridium galea,Cleistosphaeridium
diversispinosum,Distatodiniumtenerum, Impagidiniumsp.

Biozone 4: Systematophora placacantha Interval zone

This local biozone introduced by Vasilieva 1990 from Southern Ural region and by Bujak and

Mudge (1994) and Mudge and Bujak (1996) from North Sea.

Age:Early Eocene (Lutetian) Occurrence:from $158.9 \mathrm{~m}$ to $242.1 \mathrm{~m}$

Definition: this zone has been defined as the interval from the LAD of Systematophora placacantha to the LAD of Hystrichokolpoma cinctum. The companying taxa include: Distatodinium tenerum, Spiniferites mirabilis, Dapsilidinium pseudocoligerum,

Lingulodinium machaerophorom.

Systematophora placacantha has stratigraphically been recorded from Paleocene, West Tasmania (Cookson and Eisenack,1967)

Biozone5: Cordosphaeridium cantharellus Interval zone

This local biozone is being introduced here. The index species Codosphaeridium cantharellus has been reported from European region. Cordosphaeridium cantharellushas been reported from: Upper Eocene, South England (Bujaketal., 1980) ;Upper Eocene- Lower Miocene, off shore East Canada (Williams and Bujak, 1977a)Upper Middle Eocene- basal Miocene, General (Drugg and Stover, 1975)

Age: Eocene (Bartonian), Occurrence: from $242.1 \mathrm{~m}$ to $325.33 \mathrm{~m}$

Definition: this zone has been defined as the interval from the FAD of Cordosphaeridium cantharellus to the LAD of Cleistosphaeridium placacanthum . The accompanying taxa are Cordosphaeridium gracile, Distatodinium cf. biffi ,Glaphyrocysta sp., Hystrichokolpoma eisenackii.

Cordosphaeridium gracilehas been reported from Lower-Upper Eocene, South England (Bujak et al.,1980), Middle-UpperEocene, off shore North West Africa (Williams, 1978).

Biozone 6: Spiniferites pseudofurcatus Interval zone This local biozone was intruduced by Bujak and Mudge (1994) from off shore West Greenland.

Age: Late Eocene (Priabonian) Occurrence: from $350.46 \mathrm{~m}$ to $423.64 \mathrm{~m}$

Definition: this zone has been defined as the interval from the LAD of Spiniferites pseudofurcatus to the LAD of Achomosphaera alcicornu. The 
accompanying taxa include: Impagidinium sp., Operculodinium cf. microtrainum.

Spiniferite spseudofurcatus has stratigraphically been reported from Lower-Upper Eocene of South England(Bujak et al.,1980), Middle Eocene of Mexico (Helenes, 1984).

Biozone 7: Polysphaeridium zohary Interval zone Age: Early Oligocene (Rupelian), Occurrence: from $350.46 \mathrm{~m}$ to $423.6 \mathrm{~m}$

Definition: this zone has been defined as the interval from the LAD of Thalassiphora delicate to the LAD of Polysphaeridium zohary. The accompanying taxa are: Operculodinium cf. microtrainum, Melitasphaeridiumasterium, Impagidiniumsp., Fig.4. Thalassiphora delicata has been reported from Late Eocene of offshore West Greenland(NøhrHansen,2002), Homotriblium tenuispinosum has also been stratigraphically reported from Lower Oligocene of CentralItaly (Biffi and Manum, 1988), Upper Eocene, Egypt (El-Beialy, 1988b), Lower-Upper Eocene of England (Eaton,1976) and Lower-Upper Eocene of off shore East Canada (Williams and Bujak, 1977)

Table1.Correlation of Paleogene dinoflagellate cyst biozones established for Zagros basin with those of Europe and Ural

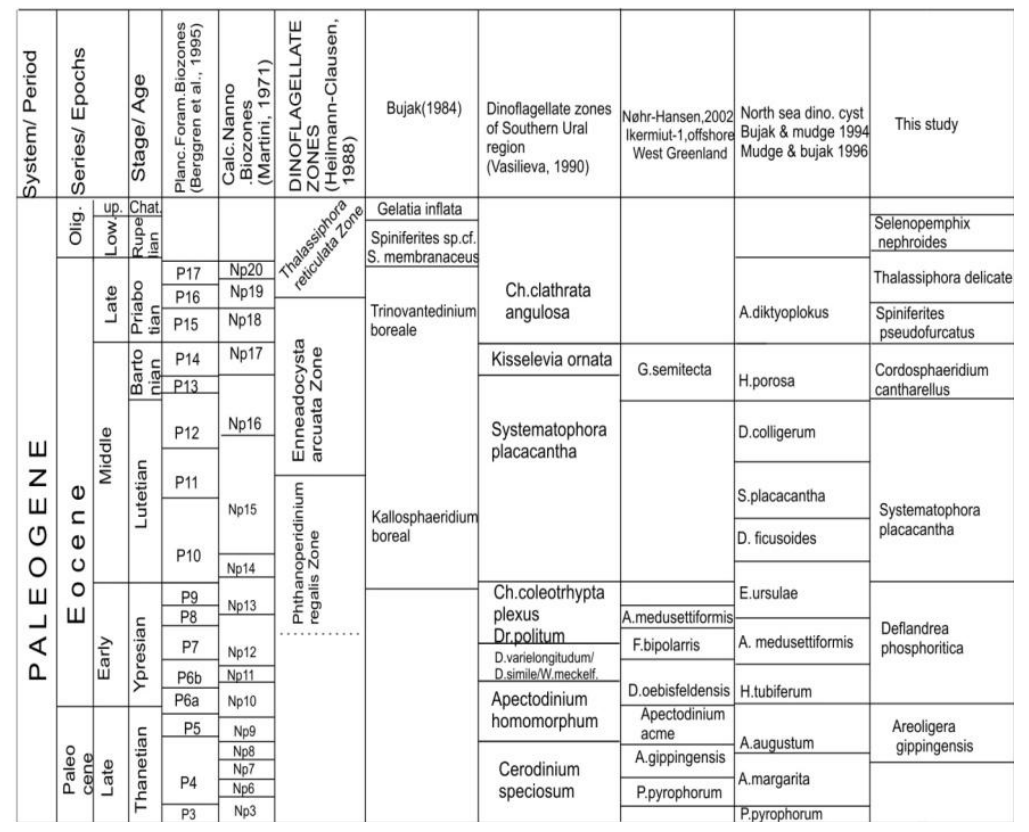

Thermalmaturity: The thermal maturity discussed and used in this study is basen on changes in spore or pollen color. Thermal maturitywas used for oil exploration as it is capable of characterizing organic matter type based on which kerogen type in the source rocks could be identified. The yellow color usually indicates a degree of maturation for the rocks that yet not attained a thermal maturation degree to generate petroleum. The brown range of color indicates a well maturation degree for oil generation. Seven samples that contain diverse assemglages of spore and pollen are selected to study for color change of their spore and pollen contents. Of these, five samples are located with in the oil prone sector and two samples indicated an over mature condition(Table 2). In general, these indicate that the Pabdeh Formation is a good source rock for the big reservoir rock unit, the Asmari Formation.
Biozone7: Selenopemphix nephroides Interval zone This local biozone is being introduced here. The nephroides has been stratigraphically reported from Lower Oligocene of Egypt (El-Bassiounietal.,1988), Upper Eocene - Lower Oligocene of Netherlands (de Coninck, 1986b), Oligocene of Nigeria (Biffi and Grignani,1983) and Oligocene of North West Age: Early Oligocene(Rupelian), Occurrence: from $421.33 \mathrm{~m}$ to $457 \mathrm{~m}$

from the LAD of Polysphaeridium zohary to the LAD of Selenopemphix nephroides. The accompanying taxon is Memranophoridium aspinatum, Fig.4.

Polysphaeridium zohary has stratigraphically been reported from Lower Eocene-Oligocene of off shore East Canada (Williams and Brideaux,1975) and Middle Eocene of Pakistan (Köthe et al.,1988). 
Table 2.Spore and pollen Color changesused for evaluation of thermal maturity

\begin{tabular}{rllll}
\hline Sample No & $\begin{array}{l}\text { Color of spore } \\
\text { andpollen grains }\end{array}$ & TAI & Maturity & Hydrocarbon \\
\hline 38 & Brown & $3+$ & Mature & Liquid petroleum \\
46 & Brown & $3+$ & Mature & Liquid petroleum \\
48 & Very Dark brown & $4-$ & Overmature & Dry gas or barren \\
54 & Light brown & $3-$ & Mature & Liquid petroleum \\
74 & Very Dark brow & $4-$ & Overmature & Liquid petroleum \\
84 & Brown & $3+$ & Mature & Liquid petroleum \\
116 & Light brown & $3-$ & Mature & Liquid petroleum
\end{tabular}

Conclusions: The Siah anticline, located in the south western Iran, contains a rich Paleocene-Oligocene record of dinoflagellate cysts. The dinoflagellate cysts are abundant in the lower and upper parts of the section but, their abundance decreases in some parts of the section because of the limestone lithology of the layers. Seven biozones are established based on the presence of dinoflagellate cysts. These
include:Areoligeragippingensis,Deflandreaphosphori tica,Systematophoraplacacantha,Cordosphaeridiumc antharellus, Spiniferitespseudofurcatus

Thalassiphoradelicata,

Selenopemphixnephroides.Thezones in general confirm the late Paleocene to early Oligocene age forthe Pabdeh Formation at this section which has also been gained from studies on foraminifera and nannofossils. Dinoflagellate cyst zones erected here are compatible with those of European countries.

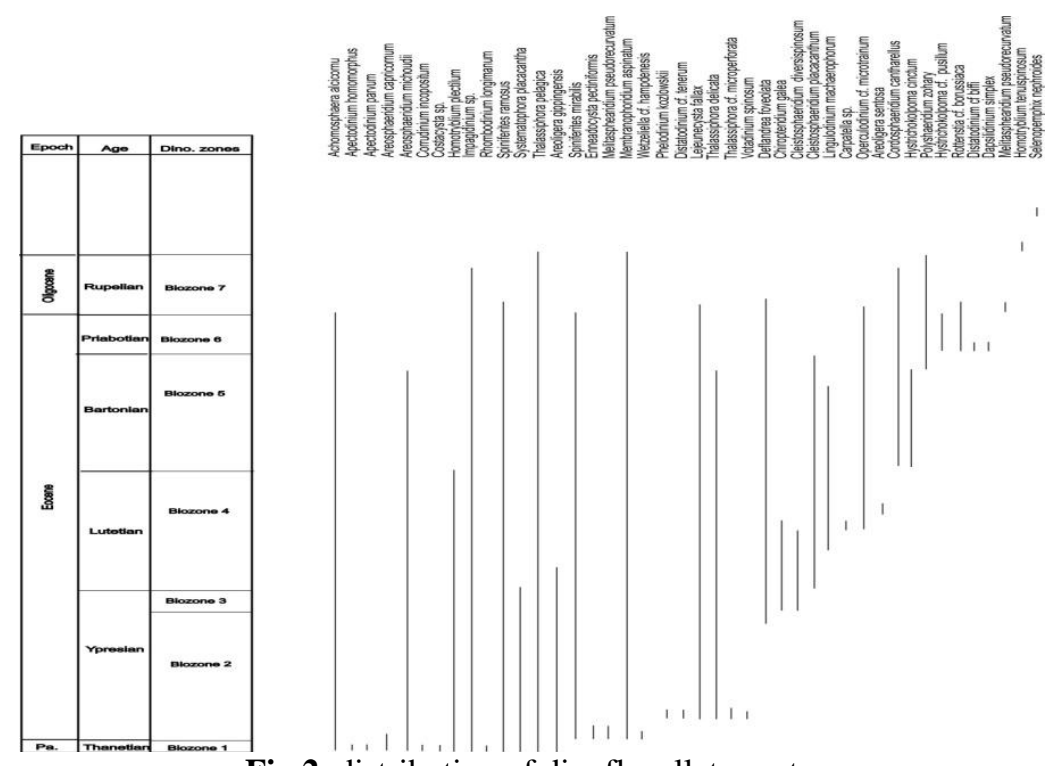

Fig 2. distribution of dinoflagellate cysts

Figure 3. scale bar $=30$ micron

1. Achomosphaera alcicornu (Eisenack,) Davey and Williams, 1966; 2. Areoligera gippingensis Jolley, 1992

3. Areosphaeridium capricornum (Cookson and Eisenack, 1965) Stover and Evitt, 1978

4. Areosphaeridium michoudii Bujak, 1994; 5. Chiropteridium galea (Maier, 1959) Sarjeant, 1983

6. Cleistosphaeridium placacanthum (Deflandre and Cookson) Eaton et al., 2001

7. Cordosphaeridium cantharellus (Brosius, 1963) Gocht, 1969; 8. Corrudinium incopositum (Drugg, 1970) Stover and Evitt, 1978; 9. Dapsilidinium simplex (White, 1842) Bujak et al., 1980; 10.Deflandrea phosphoritica Eisenack, 1938; 11.
Deflandrea foveolata Wilson, 1984; 12. Distatodinium cf. tenerum (Benedek, 1972) Eaton, 1976

Figure 4. scale bar $=30$ micron

13. Distatodinium cf. Biffi Brinkhuis et al., 1992;

14. Membranophoridium aspinatum Gerlach, 1961

15. Enneadocysta pectiniformis (Gerlach, 1961) Stover and Williams, 1995; 16.Impagidinium sp. 17. Lejeunecysta fallax (Morgenroth, 1966) Artzner and Dörhöfer, 1978; 18. Melitasphearidium pseudorecurvatum (Morgenroth 1966) Bujak et al. 1980; 19. Polysphaeridium zoharyi (Rossignol, 1962) Bujak et al., 1980; 20. Selenopemphix nephroides 
Benedek, 1972; 21. Spiniferites pseudofurcatus (Klumpp, 1953) Sarjeant, 1970

22. Hystrichokolpoma cinctum Klumpp, 1953; 23. Thalassiphora pelagica (Eisenack, 1954) Eisenack and Gocht, 1960; 24. Systematophora placacantha (Deflandre and Cookson, 1955) Davey et al., 1969

Figure 4.

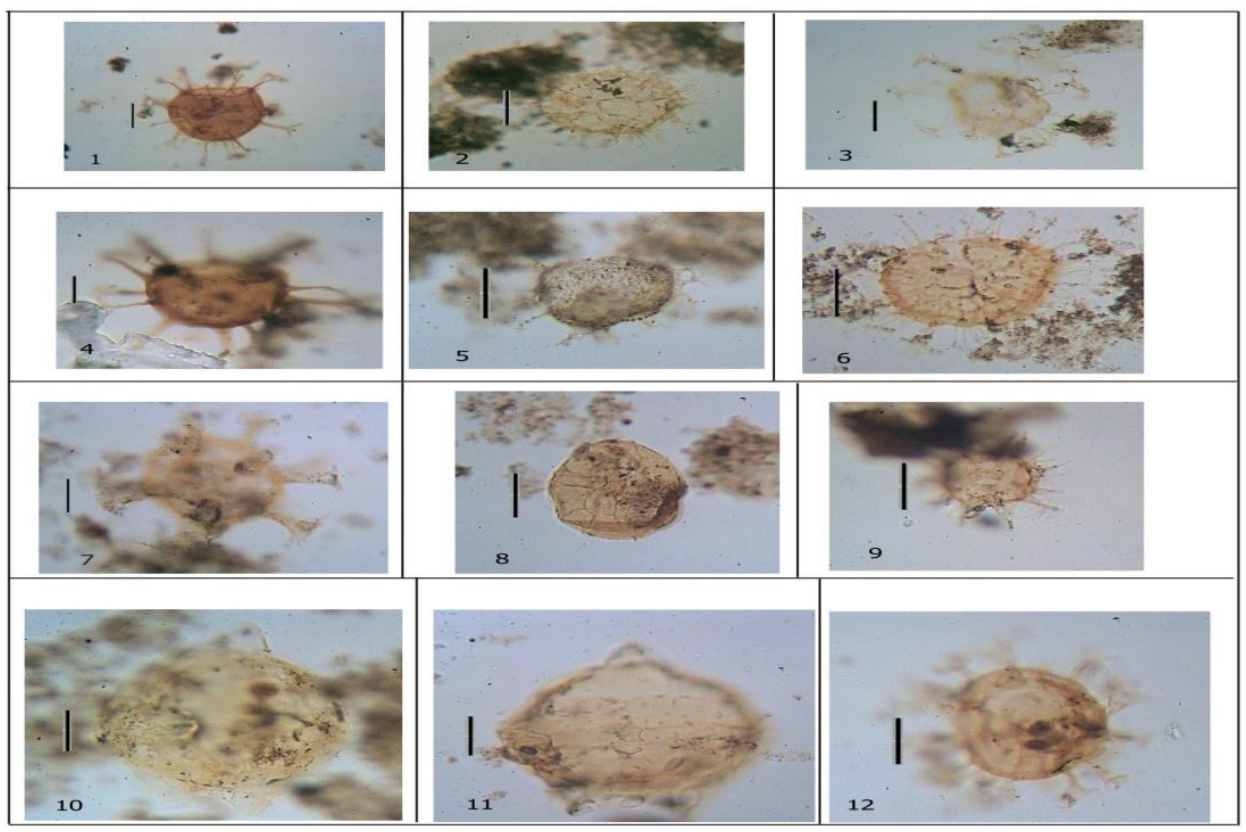

Figure 5 .

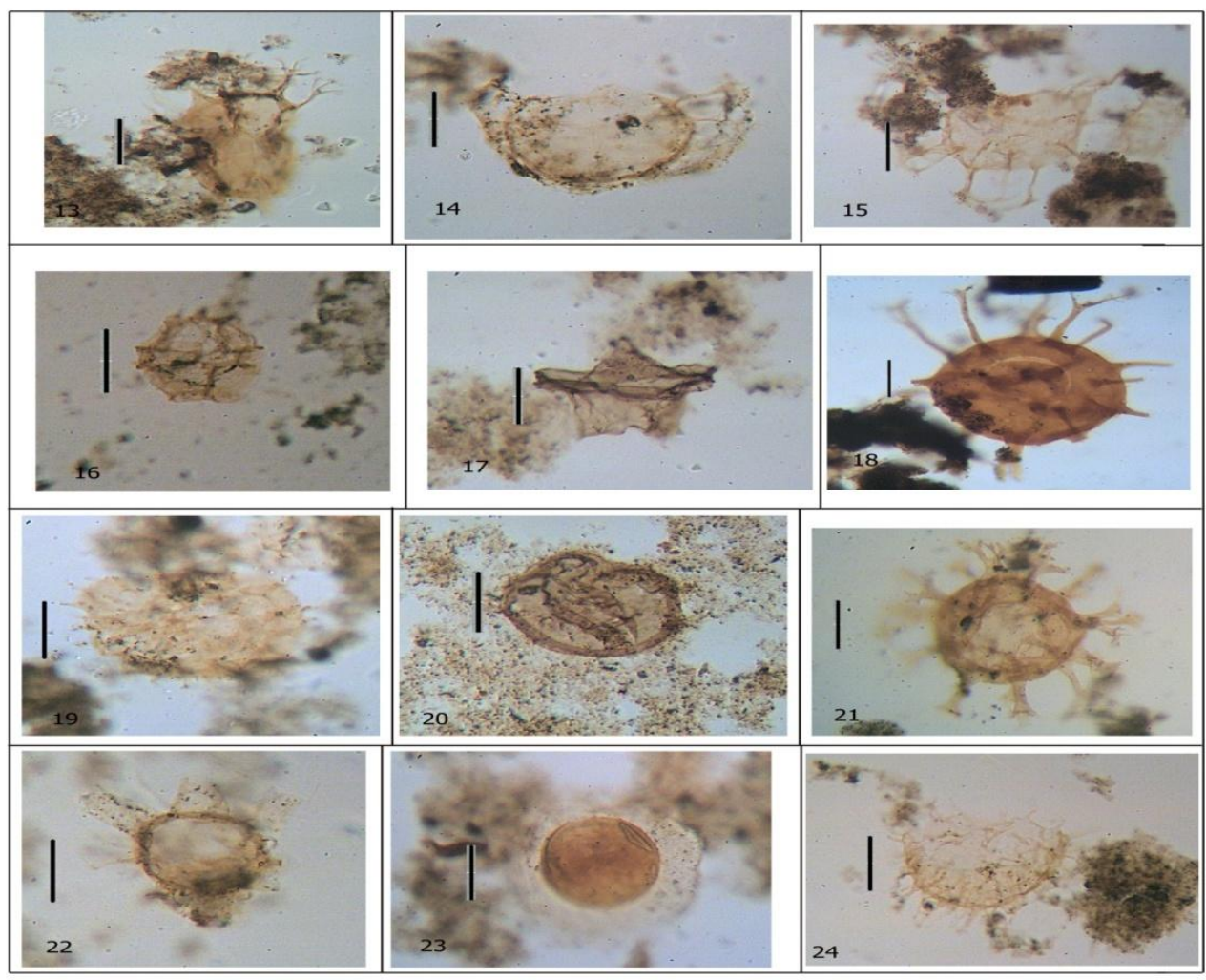




\section{REFERENCES}

Aghanabati, A. (2004). Geology of Iran. Ministry of Industry \& Mine. Iran: Geological Survey of Iran, 350pp, in Persian.

Sluijs, A., Pross, J., Brinkhuis, H. (2005). From green house to icehouse; organic-walled dinoflagellate cysts as paleoenvironmental indicators in the Paleogene.Earth-Science Reviews,68, 281-315.

Biffi,U. and Grignani, D. (1988).On the Eocene - Oligocene boundary in Alam El-Bueib IX, Western Desert, Egypt. Revista Española de Micropaleontología, 20(1):59-70.

Biffi,U., Manum, S. B.(1988). Late Eocene- Early Miocene dinoflagellate cyst stratigraphy from the Marche Region(Centralltaly). Bollettino della Società Paleontologica Italiana, 27(2):163-212.

Bujak,J.P, Downie, C, Eaton,G.L, and Williams, G. L.(1980). Dinoflagellates cyst and acritarchs from the Eocene of Southern England.The Palaeontological Association London. Specialpaperin palaeontology, 24:96

Bujak, J. P., \& Mudge, D. (1994). A high-resolution North Sea Eocene dinocyst zonation.J ournal of the Geological Society of London, 151,449-462.

Bujak,J.P. 1984. Cenozoic dinoflagellate cysts and acritarchs from the Bering Sea and northern

North Pacific, DSDP leg 19. Micropaleontology, 30:180212.

Cookson, I . C. and Eisenack,A. (1967). Some Early Tertiary microplankton and pollen grains froma deposit near Straha, western Victoria. Proccedings of the Royal Society of Victoria, 80:131-140.

Drugg, W. S. and Stover, L. E.(1975). Stratigraphic ranges charts of selected Cenozoic dinoflagellates. In: Evitt, W.R.(Ed.).,Americam Association of Stratigraphic Palinologists Foundation, Contribution Series No.4:7376.

Ghasemi-Nejad, E., Hobbi,M. H., Schiøler, P.(2006). Dinoflagellate and foraminiferal biostratigraphy of the Gurpi Formation (upper Santonian upperMaastrichtian), Zagros Mountains, Iran. Cretaceous Research, 27 , 828-835

Ghosh,S.and Zambrano, E.(1996).The Eocene turbidites of the Trujillo Formation,Venezuela Andes. Program, Caracas! IIAAPG/SVGInternational Congress and Exhibition, A18.

Gradstein, F.M., Kristiansen, I.L., Loemo, L., Kaminski, M.A.(1992). Cenozoic foraminiferal and dinoflagellate biostratigraphy of the Central North Sea. Micropaleontology 38, 101-137.

Iakovleva,A. I.,Rousseau,D. D.(2000). Paleocene-Eocene dinoflagellates cysts and continental palynomorphs from borehole no. 4 (vasugan basin, central western siberia). Palynology, $24,187-200$.
Heilmann-Clausen, C. (1988).The Danish Subbasin, Paleogene dinoflagellates. In: Vinken, R. (ed.), The north west European Tertiary basin: results of the International Geological Correlation Programme, Project No. 124. Geologisches Jahrbuch, A 100: 339343.

Heilmann-Clausen,C., Simaeys, S. V.,(2005). Dinoflagellate cysts from the central danish basin 143 dinoflagellate cysts from the middle eoceneto ?lowermostoligocene succession in the kysing research borehole, central Danish basin palynology, 29, 143-204

Holl, C, KarinA. F. Zonneveld, Helmut Willems.(2000). Organic-walled dinoflagellate cyst assemblages in the tropical Atlantic Ocean and oceanographical changes over the last 140 ka. Palaeogeography, Palaeoclimatology, Palaeoecology160, 69-90.

Jaramillo, A. C. (1999). Sequence stratigraphic in terpretations from palynofacies, dinocyst and lithological data of Upper Eocene-Lower Oligocene strata in southern Mississippi and Alabama,U. S. Gulf Coast. Palaeogeography, Palaeoclimatology, Palaeoecology145, 259-302.

Köthe, A. (1990). Paleogene Dinoflagellates from North west Germany- Biostratigraphy and Paleoenvironment. Geologisches Jahrbuch, A118: 3-111.

Morgans, H.E.G., Beu,G., Cooper, R.A, Crouch, E.M., Hollis,C.J., Jones, C.M., Raine, J.I., Strong, C.P., Wilson, G.J., Wilson, G.S., (2004).Paleogene.In: Cooper Ra ed. (2004). The New Zealand geological timescale. Institute of Geological and Nuclear Sciences Monograph 22

Motiei,H.(2003). Geology of Iran: Stratigraphy of Zagros. Geological survey of Iran.343-363pp, in Persian.

Nøhr-Hansen, H.(2003). Dinoflagellate cyst stratigraphy of the Palaeogene strata from the Hellefisk-1, Ikermiut-1, Kanga ^miut-1,Nukik-1, Nukik-2 and Qulleq-1 wells, offshore West Greenland Marine and Petroleum Geology, 20, 987-1016.

Norris, G. and Velásquez, M.(1994).Senonian through Pliocene zonation based on dinoflagellate and other organic walledalgal microfossils with catalog of dinoflagellate species with description supported by photomicrographs, Western Venezuela. Maraven Exploración y Producción Caracas. Informetécnico EPC-13435: $51 \mathrm{p}$.

Rabbani, J. ,Ghasemi-Nejad, E. ,Ashori, A., Vahidinia, M.(2013).Quantitative palynostratigraphy and palaeoecology of Tethyan Paleocene-Eocene red beds in north of Zagros sedimentary basin, Iran. Arabian Journal of Geosciences DOI 10.1007/s12517-013 $1164-2$ 